\title{
SURVEY OF ISLAMIC ART IN THE HOLY SHRINE OF GHASEM (AS) UREH IN THE DAMAVAND CITY OF TEHRAN PROVINCE
}

\author{
Atieh Youzbashi \\ Master of Visual Communication, Faculty of Art, Shahed University, Tehran, Iran \\ atiehyouzbashi@yahoo.com \\ Seyed Nezam Oldin Emamifar \\ Assistant Professor of Faculty of Art, Shahed University, Tehran, Iran \\ n_emamifar@yahoo.com
}

\begin{abstract}
Islamic art or the arts of Muslims is a part of art in Muslim society and not necessarily by Muslims. Although in some cases, this arts may not go with the ethics and rules of Islam. The impact of Islamic and regional culture in this arts is obvious. Islamic art is not an art that is only related to Islam. The "Islamic" does not only refer to the religion but also it refers to the rich culture and different types of people who live in Islamic lands. Familiarity with Islamic art in the shrines and the pictorial motifs in them leads to getting familiar with semiology. Arts used in the shrines are one of the most obvious representatives of Islamic culture and spiritual atmosphere. The way of doing the research is based upon the descriptive and analytic nature, and the way of compiling information is combined. The way of taking sample is not random (Chosen) and the way of interpreting and analyzing the information is both qualitative.

Initially in this research, the basic of Islamic art are introduced and then the example of Islamic art in the shrine of Ghasem (AS) which include, wood carving, fretwork, girih tile, illumination and reticulated metal. Motifs and signs and other features are shown in tables and diagrams and one motif is analyzed semiologically. Getting the meaning and understanding the patterns and motifs necessitate deep study. This essay is to consider pictorial motifs, religious beliefs and symbolic meaning in the Islamic art. In the Islamic art, we faced the repeated elements, like; the use of geometric patterns or non-realistic drawing of a flower or plant that is called arabesque. Arabesque motifs in Islamic art are often used as the symbol of a very vast universe which is created by God. Deliberation in not showing and imitating nature exactly is said to be as a sign of the modesty of the artists who believe, creation of perfection is just for god, as a result in the motifs and decoration of Damavand shrine, the flowers and plants that are specific for that region is not used.
\end{abstract}

Keywords: Islamic art, shrine, Damavand city, the shrine of Ghasem (AS) Ureh, Semiology

\section{INTRODUCTION}

Motifs and patterns make a dynamic relationship between society and art and these motifs, whether inspired by regional culture of people or foreign cultures or Islamic culture, play an important role in assigning the decorative elements of present time and feature.

Generally tomb is one or more religious or political characters are buried, this type of monuments is divided into two categories, Religious tombs (shrine), non-religious tombs.

Iranian artist have had a very important prophecy in choosing natural forms for decorating the monuments and their aim was to make a connection between material and spiritual world. Therefore, the motifs used 
by them are based on special concepts, not just for decorating objects and monuments. $<$ Decoration which is the main source of Iran, is not just for joy or pleasure, it has deeper meaning> (Pope, 1380, p.2) as a result despite various concepts between Iranian art and other cultures and civilization throughout the history. New features have been created with fidelity to old Islamic tradition that Iranian Islamic identity is clear in them.

Motifs and decorative patterns are a treasure resulted from Iranian-Islamic art and culture. Iranian artists used common patterns because of being conservative and traditional.

After the rise of Islam this religious, socially, cultural, politically and financially affected the societies. Art was also influenced and transformed by this religion and was recognized with a new name as Islamic art. Islamic art as the name suggests, was improved and developed in different historical and geographical eras after the rise of Islam. Many researchers in their works have introduced this art in different historical eras and have defined this art and almost with common examples they have given various theories and definitions of this art. Revising the analysis and interpretations that are already done. About Islamic art and definition of its nature, is for gaining a majestic and holy art in our contemporary time. Because art impress societies and people to a great extent.

By analyzing the achievement of the researchers in this field. Eight perspectives are recognized the art of Islamic lands, the art of Muslims. Art inspired by scriptures geometric and abstract art, holy art, religious art, Islamic art includes all above.

We may rarely find an art that is attached to people leaves as graphic and architecture. The architecture of the shrine is one of the most obvious examples of Islamic art and show the spiritual atmosphere. Decorations, motifs, patterns, compounds and coordination of all make the view of the monuments. Motifs used in the shrines are an issue that has attracted the attention of the artists. Plant and geometric motifs have made various fields for research and analysis. I fact these motifs and majestic decoration in the shrines are one of the most spiritual, beautiful, and attractive arts in religious places. In this research we are to find out whether this motifs are related to the beliefs and plants of Damavand or not used also it is going to define the Islamic art in shrine of Ghasem (AS).

\section{ISLAMIC ART}

Islamic art or the arts of Muslims is a part of art in Muslim society and not necessary by Muslims. Although in some cases, these arts may not go with the ethics and rules of Islam, the impact of Islamic and regional culture in these arts is obvious. Islamic art is one of the most magnificent periods in the history of art and is one of the most valuable human achievement in

The field of art. And includes different types of art such as calligraphy, architecture, painting, girih tile. Islamic art is not an art that is only related to Islam. The word Islamic does not refer to the rich culture and different types of people who live in Islamic lands. Islamic art also contains secular elements which are not considered as a taboo by Islamic clergyman. (Davies, 2007, p 277)

In Islamic scriptures (Quran) and the instructions of the prophet of Islam. There are a few issues about art. In Quran showing the pictures of living creatures is directly barred and as a result, many Muslims have considered the drawing of living creatures faces as a danger as blasphemy and it is believed to be a sin. Therefore Islamic art often concentrates on beauty creation with the use of letters and abstract motifs. Because of these restrictions comparing with other arts such as painting, sculpture, music (sometimes these arts are considered sinful). Muslims have developed different styles in the abstract field. (Javaher ol Kalam, v.22, p.41; Man la yahzarat ol faghieh, v.4, p.5) 
Picturing the prophet of Islam is rejected by most of the Muslims and sometimes even picturing any creature or human being is not acceptable. Despite this fact, in Islamic lands there has always been picturing of the face of the prophet. In addition to the rejection of picturing the prophet, mental image or perception of God as we see In Hinduism and Christianity is not common in Islam. All these geographical, social, cultural reasons and competition with other civilizations led to the special attention of the Islamic artists to abstract arts such as calligraphy, geometric motifs or arabesque and architecture. Islamic art is much more limited than Christian or Buddhist art that specifically uses forms of art such as sculpture, painting, music or dance, in the churches or temples. "Servat Akasheh" distinguished Egyptian researcher writes: < religious painting in the initial periods of Islam was not acceptable and admired as it was in Buddhism or Christianity mosques were empty of religious paintings and painting was not used for religious instructions and making religious believes unity $14^{\text {th }} \mathrm{C}(\mathrm{AH})$ (Akasheh, 1380, p.107)

In Islamic art we face repeated elements, like the use of geometric patterns or a non-realistic drawing of a flower or plant that is called arabesque. Arabesque motifs in Islamic art are often used as the symbol of a very vast universe that is created by God. Although it is not accepted by all. The deliberation is not showing and imitating the nature exactly is said to be a sign of the modesty of the artists who believed that creation of perfection is just for God.

\section{ISLAMIC ART, MANIFESTATION OF ORIGINAL SPIRITUAL ART}

Although orientalists have named art coordinates among the Muslims a decorative art, we must beware that definition is due to their back of aware uses about the secrets and meaning of this type of art that only shows monotheism. These arts have chosen a way in which no element could say,"Me" (no Individual) (Borkheart, 1373) the elements of these arts are not individual like icon, pictures and some geometric forms to express themselves or even to try to establish a spiritual value on their own. These elements are reduced in totality and universality to a great extent that they can only refer to monotheism, and moreover Islamic art is free from the individuality of the artists, even time and place and elements. By looking at arabesque motifs we could easily find out that they are free from time and place and it could only refer to monotheism. (Naghizadeh, 1387, p.217)

We could say that art is a manifestation of spiritual aspects of human beings in nature that sometimes serves the divine thoughts of human beings and sometimes serves the instincts. Islamic art is an art that is the manifestation of human spirituality and commitments and improves the thoughts and actions of human being and does not weaken and misguide human thoughts and action.

An art which only serves the instinct and material aspects of life and is in the series of malice and malicious people is an inferior and non-religious art.

The rise of Islamic art out of religion and new governments was not gradually and step by step, like Islam itself was a sudden process. Most of the elements forming and decorating the monuments in the initial eras of Islam were affected by Muslims, serving some purposes that were not available before Islam.

Islamic art to develop itself was inspired by many sources; Roman art, Initial Christian art and Bizans art were influential in Islamic art and architecture. The impact of Sassanid art in Iran before Islam was more important, later different styles and elements from middle Asia and China during the invading of Moguls impressed Islamic painting, pottery and textile a lot.

In Islamic scriptures (Quran) and the instructions of the prophet of Islam. There are a few issues about art. In Quran showing the pictures of living creatures is directly barred and as a result, many Muslims have considered the drawing of living creatures faces as a danger as blasphemy and it is believed to be a sin. Therefore Islamic art often concentrates on beauty creation with the use of letters and abstract motifs. 
Because of these restrictions comparing with other arts such as painting, sculpture, music (sometimes these arts are considered sinful). Muslims have developed different styles in the abstract field. (Javaher ol Kalam, v.22, p.41; Man la yahzarat ol faghieh, v.4, p.5)

Picturing the prophet of Islam is rejected by most of the Muslims and sometimes even picturing any creature or human being is not acceptable. Despite this fact, in Islamic lands there has always been picturing of the face of the prophet. In addition to the rejection of picturing the prophet, mental image or perception of God as we see In Hinduism and Christianity is not common in Islam. All these geographical, social, cultural reasons and competition with other civilizations led to the special attention of the Islamic artists to abstract arts such as calligraphy, geometric motifs or arabesque and architecture. Islamic art is much more limited than Christian or Buddhist art that specifically uses forms of art such as sculpture, painting, music or dance, in the churches or temples. "Servat Akasheh" distinguished Egyptian researcher writes: <religious painting in the initial periods of Islam was not acceptable and admired as it was in Buddhism or Christianity mosques were empty of religious paintings and painting was not used for religious instructions and making religious believes unity $14^{\text {th }} \mathrm{C}(\mathrm{AH})$ (Akasheh, 1380, p.107)

\section{RELIGIOUS ART}

The most fundamental part of art is the divine art that is connected to the spiritual life of human being religious art is an art that has taken its concepts from religion but it implies the religious fundamentals in a way that is more indirect. For instance; graphics in comparison with Quran as a divine art. The term "Divine" especially when it is used in art. Only shows a series of traditional manifestation which are directly connected to the spiritual fundamentals mentioned above.

\section{RELATION BETWEEN RELIGION AND ART}

Art takes its rules, fundamentals and values from the ontology and culture dominant in society or in other word from the beliefs of the artists, and religion with its totality and domination over the body and soul of human being is the is the most suitable source for spiritual art, religion guides the art to show what is needed for human bliss in a suitable and attractive way. (Naghizadeh, 1387, p.87)

\section{THE HOLY SHRINE OF GHASEM (AS), UREH}

\begin{tabular}{|l|l|}
\hline I holy Shrine of Ghasem (AS), Ureh & $\begin{array}{l}\text { Name of } \\
\text { shrine }\end{array}$ \\
\hline Damavand, 17 shahrivar Sq, Dashte mazar St, opposite the cemetery & location \\
\hline $6^{\text {th }} \& 7^{\text {th }}$ AD & $\begin{array}{l}\text { Date of } \\
\text { construction }\end{array}$ \\
\hline $\begin{array}{l}\text { Red stone, cobalt stone, gray stone, brick, aza } \\
\text { reh, stone }\end{array}$ & $\begin{array}{l}\text { inside view } \\
\text { materials }\end{array}$ \\
\hline Brick, white cemon & $\begin{array}{l}\text { outside view } \\
\text { materials }\end{array}$ \\
\hline $\begin{array}{l}\text { Round dome from inside, stone, mirror } \\
\text { Galvanized steel, golden }\end{array}$ & $\begin{array}{l}\text { Roof } \\
\text { materials }\end{array}$ \\
\hline stone & $\begin{array}{l}\text { Floor } \\
\text { materials }\end{array}$ \\
\hline Pyramidal dome & Dome kind \\
\hline No & minaret \\
\hline
\end{tabular}




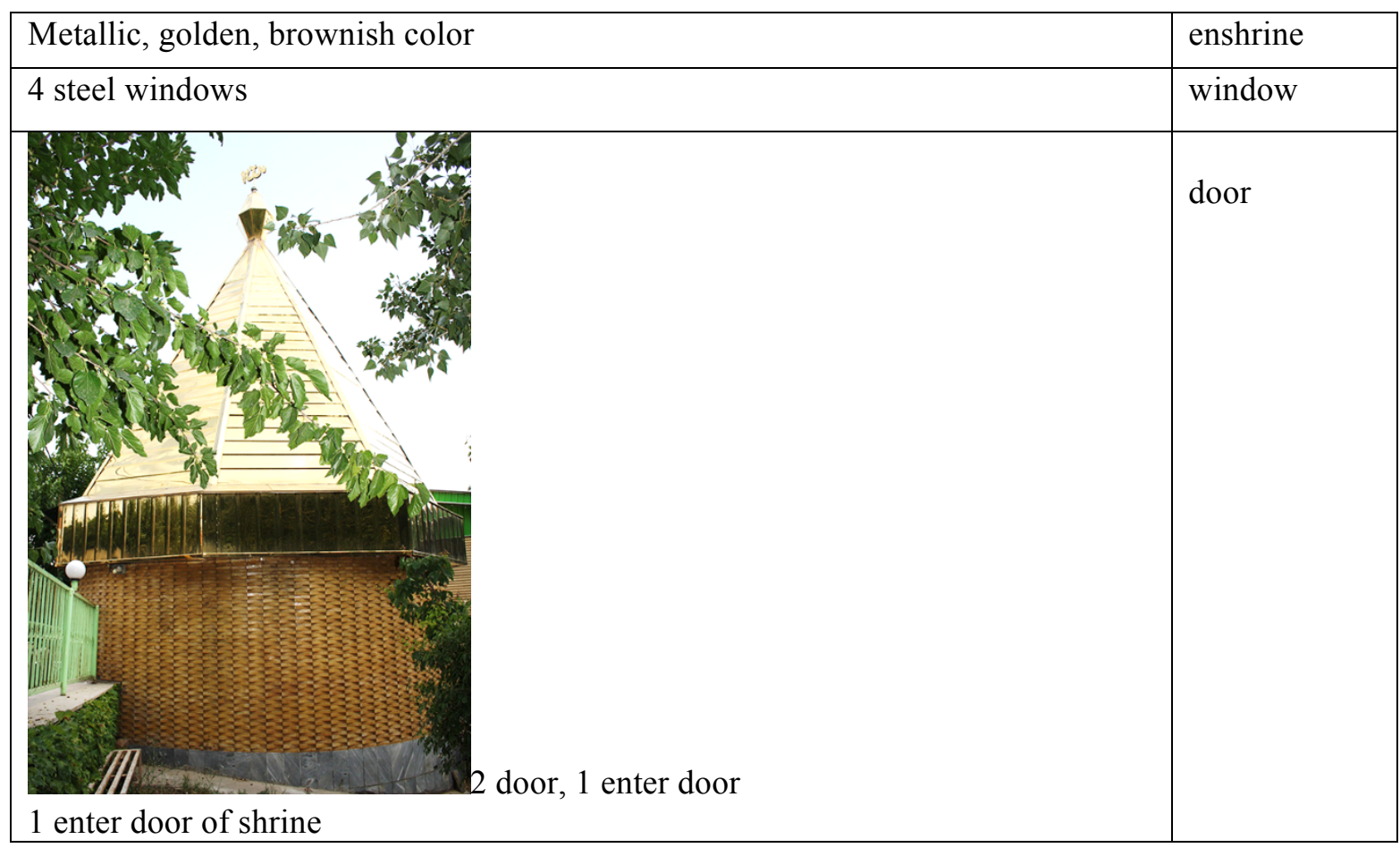

Table 1. General skim on holy Shrine of Ghasem (AS), Ureh. Source; Negarandegan.

The holy shrine of Ghasem (AS) in located in Damavand, the Ureh village, two kilometers from north away from the main mosque. The monument of the shrine includes a tower which is circular outside and octagonal inside and each side there is an arch in the form of mound.

The vast vicinity of the shrine nowadays is used as cemetery for the people of that era. The antiquity of this monument in comparison with architecture style of other holy monuments in the regions probably due to $6^{\text {th }}$ or $7^{\text {th }} \mathrm{AH} \mathrm{C}$. Islamic arts in this shrine contains; wood carving, girih tile, enamelware, gilding, mirror working, fretwork the reticulated metal.

Table 2. All Motifs of Holy Shrine of Ghasem (AS)

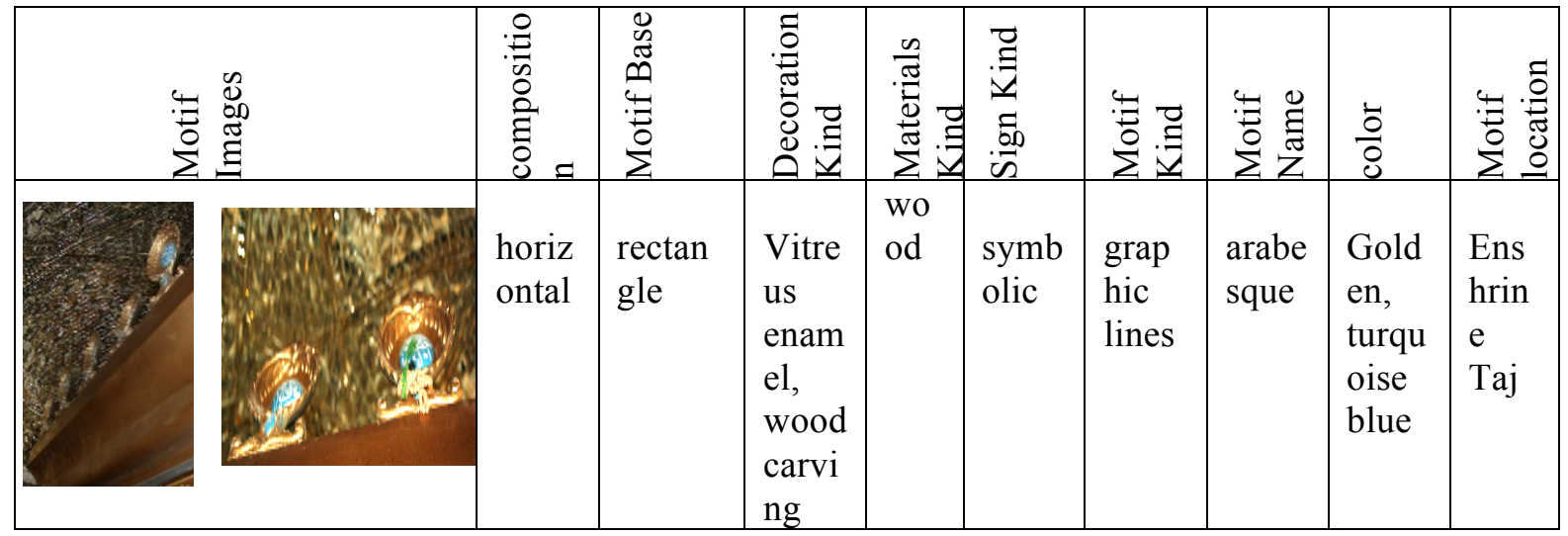




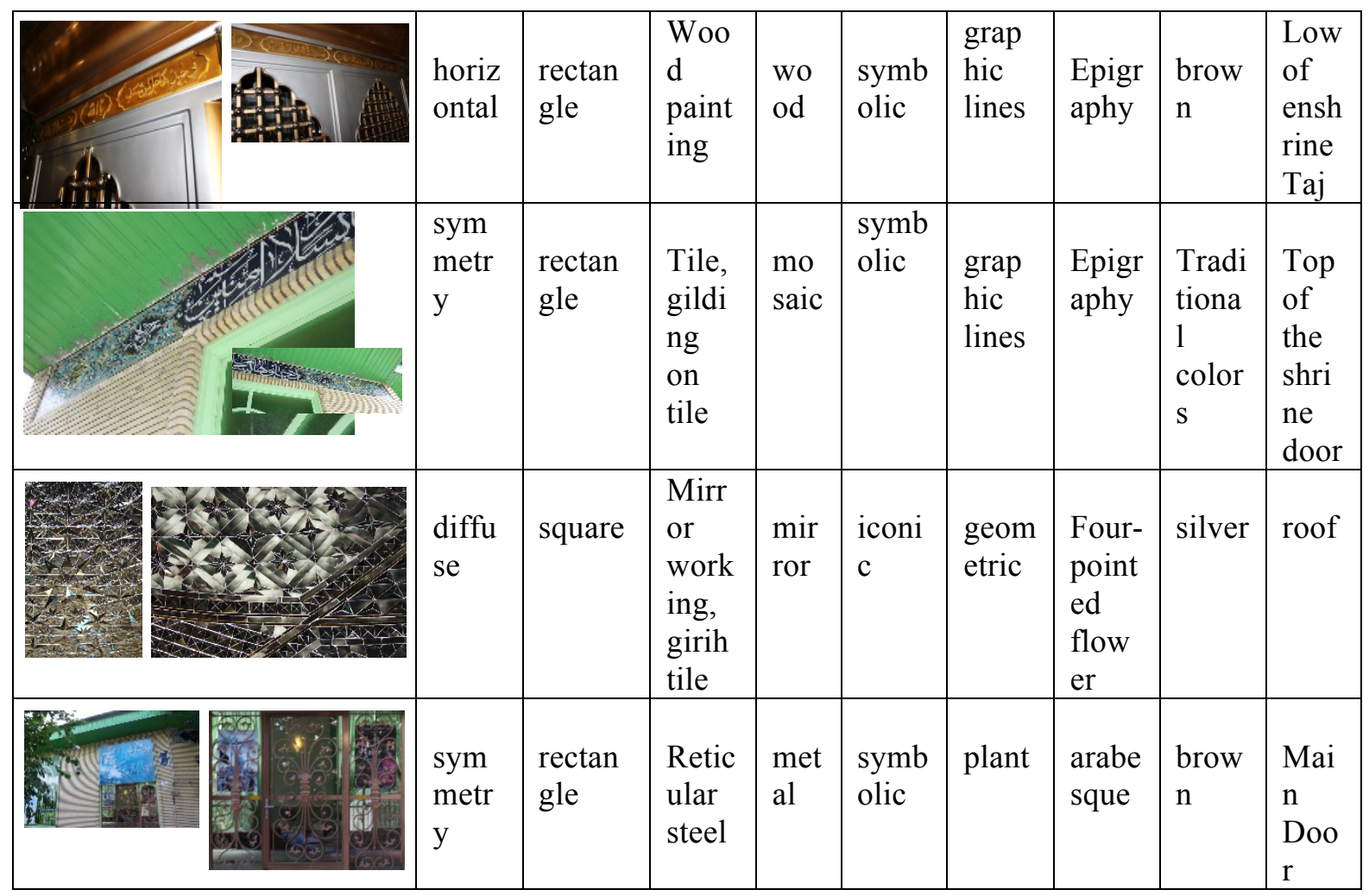
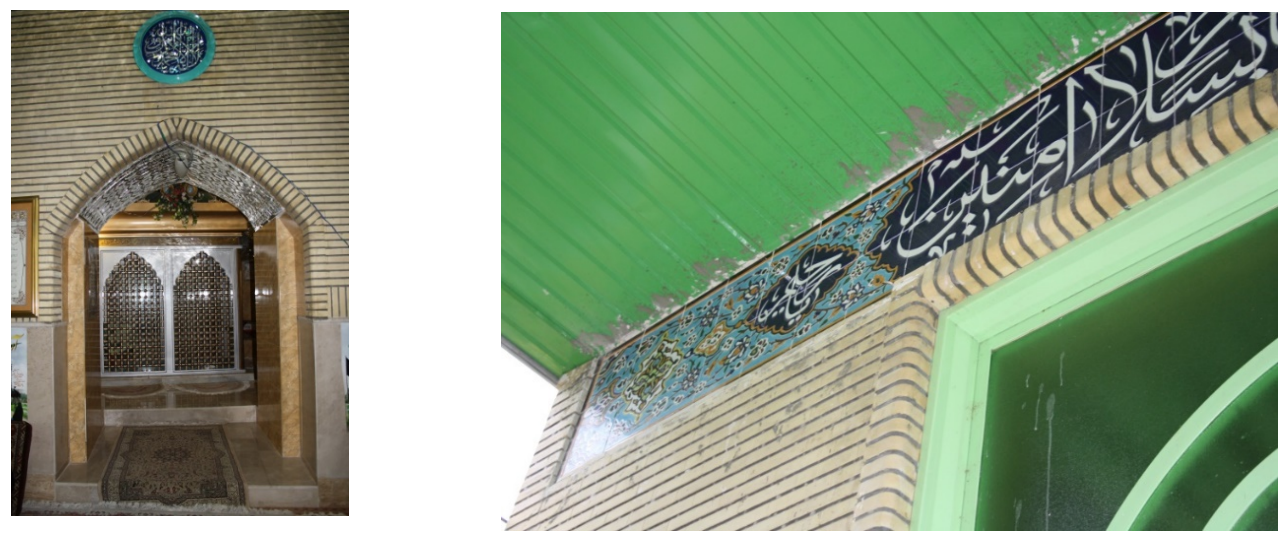

Image 1. Islamic Arts, Holy Shrine of Ghasem (AS) Ureh; source: Atieh Youzbashi

Table 3. Frequently distribution results of the study of motifs in Shrine of Ghasem (AS) Ureh

\begin{tabular}{|l|l|l|l|l|l|l|l|l|l|l|}
\hline $\begin{array}{l}\text { percentag } \\
\mathrm{e}\end{array}$ & $\begin{array}{l}\text { Motif } \\
\text { numbe } \\
\mathrm{r}\end{array}$ & $\begin{array}{l}\text { sanctuar } \\
\mathrm{y}\end{array}$ & $\begin{array}{l}\text { Outsid } \\
\mathrm{e} \text { wall }\end{array}$ & $\begin{array}{l}\text { Insid } \\
\mathrm{e} \\
\text { wall }\end{array}$ & $\begin{array}{l}\text { colum } \\
\mathrm{n}\end{array}$ & $\begin{array}{l}\text { roo } \\
\mathrm{f}\end{array}$ & $\begin{array}{l}\text { windo } \\
\mathrm{w}\end{array}$ & $\begin{array}{l}\text { doo } \\
\mathrm{r}\end{array}$ & $\begin{array}{l}\text { enshrin } \\
\mathrm{e}\end{array}$ & $\begin{array}{l}\text { Locations } \\
\text { and motifs } \\
\text { kind }\end{array}$ \\
\hline$\% 20$ & 1 & & & & & 1 & & & & $\begin{array}{l}\text { Geometric } \\
\text { al motifs }\end{array}$ \\
\hline & & & & & & & & & & $\begin{array}{l}\text { animal } \\
\text { motifs }\end{array}$ \\
\hline
\end{tabular}




\begin{tabular}{|l|l|l|l|l|l|l|l|l|l|l|}
\hline$\% 20$ & 1 & & & & & & & 1 & & $\begin{array}{l}\text { plant } \\
\text { motifs }\end{array}$ \\
\hline$\% 60$ & 3 & & & & & & & 1 & 2 & $\begin{array}{l}\text { graphic } \\
\text { lines }\end{array}$ \\
\hline$\% 100$ & 5 & & & & & 1 & & 2 & 2 & $\begin{array}{l}\text { Motif } \\
\text { Number }\end{array}$ \\
\hline
\end{tabular}

Diagram 1. Frequently distribution results of the study of motifs in Shrine of Ghasem (AS) Ureh. based on subjective division, source; Negarandegan

geometrical motifs $\quad$ animal motifs $\quad$ plant motifs $\quad$ graphic lines

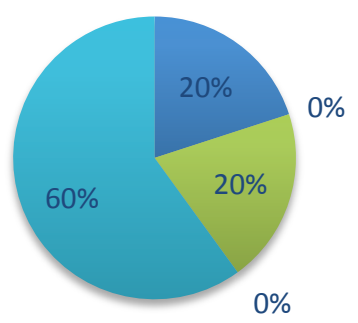

By considering the analysis of the motifs in shrine of Ghasem (AS), which are of five motifs, in a square, frequency and percentage are as below: Graphic lines $3 \& 60 \%$ - geometric and plant motifs each $1 \&$ $20 \%$ - no animal motifs are used. (Table 3, diagram 1)

Table 3. Frequently distribution results of the study of sign in Shrine of Ghasem (AS) Ureh

\begin{tabular}{|l|l|l|l|l|l|l|l|l|l|l|}
\hline $\begin{array}{l}\text { percentag } \\
\mathrm{e}\end{array}$ & $\begin{array}{l}\text { Motif } \\
\text { numbe } \\
\mathrm{r}\end{array}$ & $\begin{array}{l}\text { sanctuar } \\
\mathrm{y}\end{array}$ & $\begin{array}{l}\text { Outsid } \\
\text { e wall }\end{array}$ & $\begin{array}{l}\text { Insid } \\
\mathrm{e} \\
\text { wall }\end{array}$ & $\begin{array}{l}\text { colum } \\
\mathrm{n}\end{array}$ & $\begin{array}{l}\text { roo } \\
\mathrm{f}\end{array}$ & $\begin{array}{l}\text { windo } \\
\mathrm{w}\end{array}$ & $\begin{array}{l}\text { doo } \\
\mathrm{r}\end{array}$ & $\begin{array}{l}\text { enshrin } \\
\mathrm{e}\end{array}$ & $\begin{array}{l}\text { Location } \\
\text { s rand } \\
\text { sign kind }\end{array}$ \\
\hline$\% 80$ & 4 & & & & & & & 2 & 2 & $\begin{array}{l}\text { Symboli } \\
\text { c sign }\end{array}$ \\
\hline$\% 20$ & 1 & & & & & 1 & & & & $\begin{array}{l}\text { Visual } \\
\text { sign }\end{array}$ \\
\hline$\% 100$ & 5 & & & & & 1 & & 2 & 2 & $\begin{array}{l}\text { sign } \\
\text { sign } \\
\text { Number }\end{array}$ \\
\hline
\end{tabular}


Diagram 1. Frequently distribution results of the study of sign in Shrine of Ghasem (AS) Ureh. based on Piers division, source; Negarandegan

$$
\text { symbolic sign } \quad \text { visual sign } \quad \text { Iconic sign }
$$

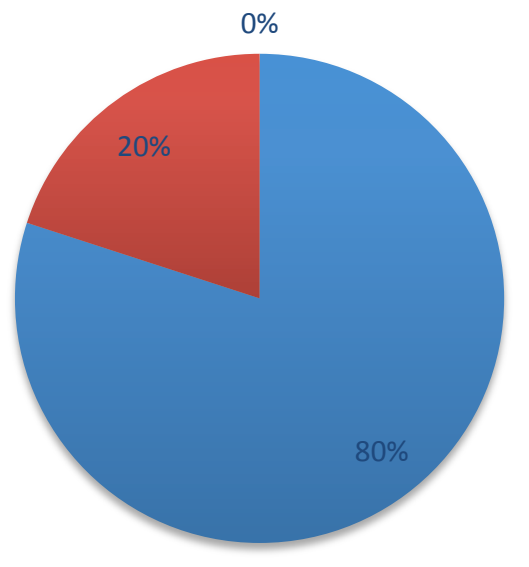

By regarding the Semiological analysis of the Ghasem shrine which has five sign, in a sequence, frequency and percentage are as below:

Symbolic sign $4 \& 80 \%$ - visual sign $1 \& 20 \%$ - Namayeh sign is not used. (Table 4 , diagram 2 )
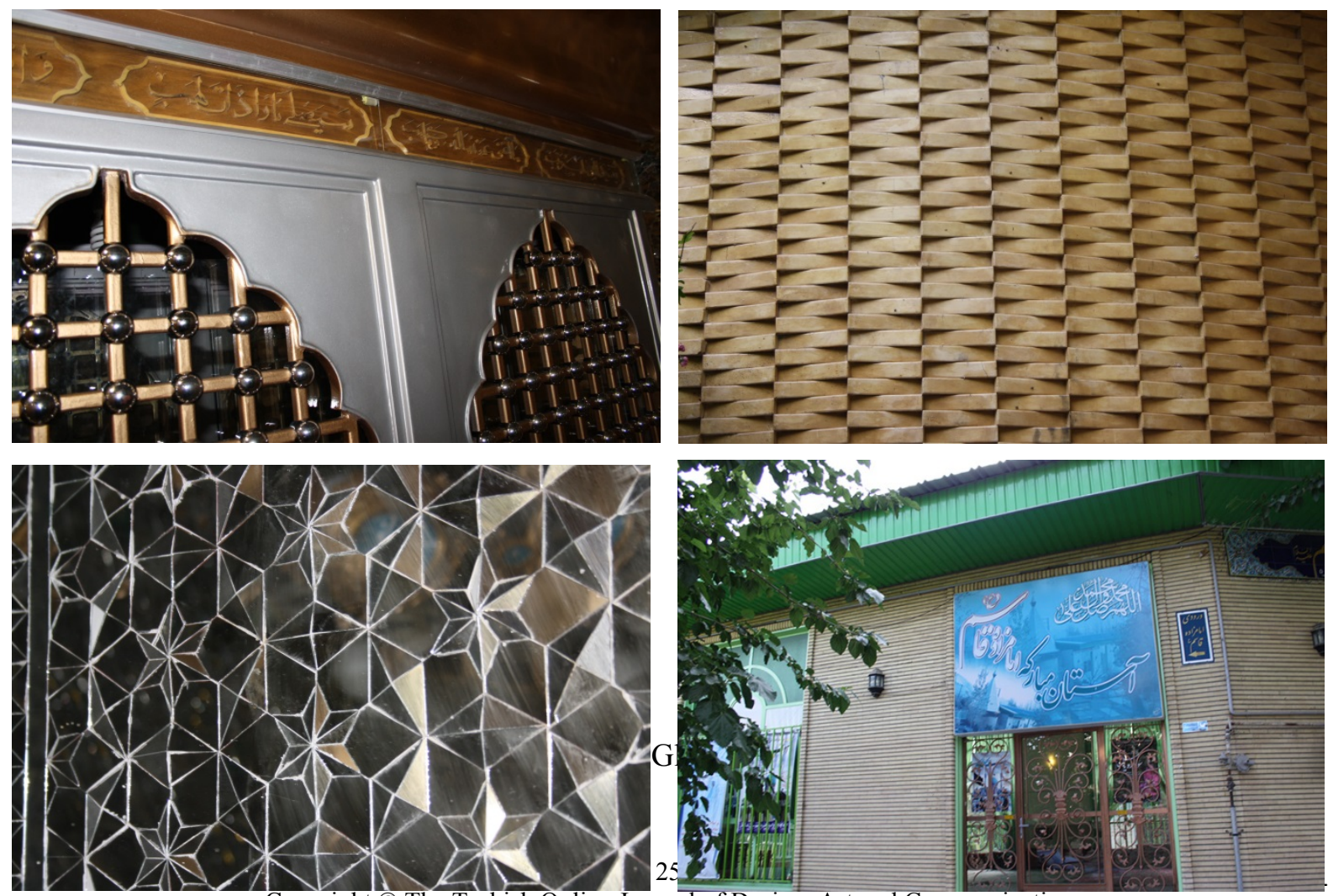

Copyright (C) The Turkish Online Journal of Design, Art and Communication 
THE CEILING PATTERN OF GHASEM SHRINE, UREH

Table 5. The Ceiling Pattern of Ghasem Shrine, Ureh, geometric four-sided flower, source; Negarandegan

\begin{tabular}{|c|c|c|c|c|c|c|c|c|}
\hline \multicolumn{9}{|c|}{ Ghasem (AS) Shrine: Damavand, 17 shahrivar Sq, Dashte mazar St, opposite the cemetery } \\
\hline \multicolumn{9}{|c|}{ Forming visual elements: spot, line, surface, volume } \\
\hline 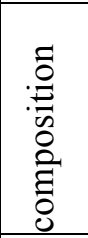 & 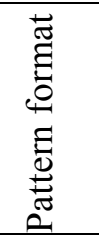 & 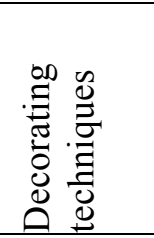 & 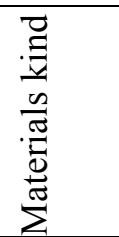 & 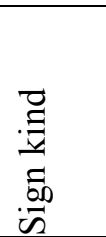 & 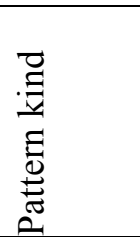 & 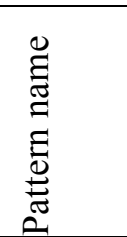 & $\frac{0}{0}$ & 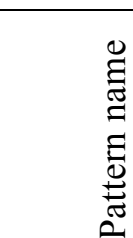 \\
\hline $\begin{array}{l}\text { diff } \\
\text { use }\end{array}$ & $\begin{array}{l}\text { squa } \\
\text { re }\end{array}$ & $\begin{array}{l}\text { Mirror } \\
\text { working }\end{array}$ & mirror & visual & $\begin{array}{l}\text { geometr } \\
\text { ic }\end{array}$ & $\begin{array}{l}\text { Four- } \\
\text { sided } \\
\text { flower }\end{array}$ & silver & ceiling \\
\hline
\end{tabular}

\section{EXPLICIT DENOTATION SURVEY}

In this style of mirror working, first the stringing is done, thus geometric motif is silver and there is a big geometric tetramerous star in the middle of the square and there are four squares in ten corners and each one of the square are made of four triangle and between these squares there is a rectangle. Symmetrical combination is used in forming the motif and this combination is in all parts of the monument. (Table 5, image 3)

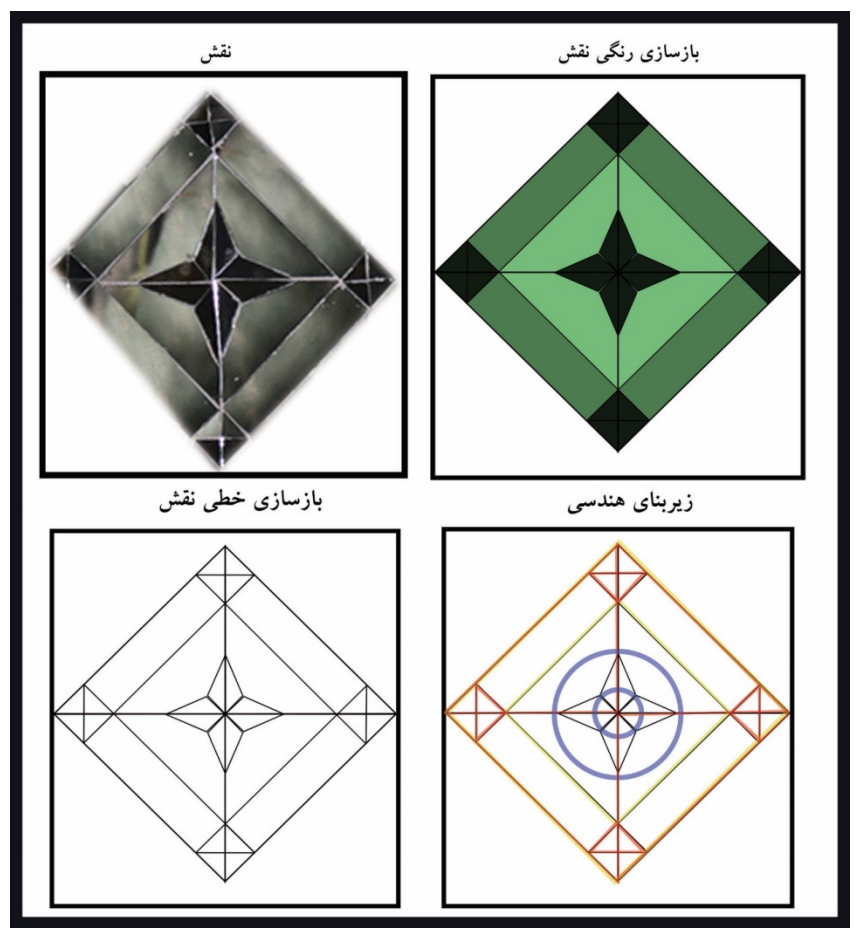

Image 3. The Ceiling Pattern of Ghasem Shrine, Ureh. Linier and color reconstruction of pattern and geometrical base; source: Negarandegan 


\section{IMPLIED DENOTATION SURVEY}

Mirror decoration is deeply rooted in Iranian mystical tradition and their spiritual beliefs. The first sign or mirror was to show man's face. Maybe it is better to know that the cause of appearing the mirror was that man wanted to see himself clearly. But mirror decoration introduce it as a spiritual foundation. In fact according to what could have been seen in eastern mysticism and especially from the some mystic points of view such as Rumi is to pass from materiality to reach the sublime the universe or nature divine. Actually, for reaching the fact in which is the existence of god. One should relinguish himself, so far perfection and joiner could achieved, as Rumi introduced the way to righteous by skip and ignoring the world.

When a mirror breaks or cracks at its surface it shows figures fragmented, that this refers to two mystical beliefs. First fragmentation that is irony of smashing of face which is for achieving the righteous.

And the second one is the creation of multiple images of a single object. Normally, a mirror shows just one image but as soon as it cracks thousands image appears. In fact the viewer finds his face in the mirror for thousands times. This issue could be regarded as a sign of unity in diversity. Thus we could say that the mirror is reminiscent in Persian architecture. The unity of creation and the creatures of universe is to guide the religious person. Apart from these two features in Persian architecture mirror decoration is manifested as well as light. Mirror reflects light and increase its effect thus we could say Persian mirror decoration motifs are taken from girih tile and this patterns are themselves a visualization of nothing except praying. Hence it can be said that mirror decoration is an art that interests its viewers to the absolute nature of god and is an unquestioned embodiment of religious art. (www.honarnews.com)

Girihs, are the Persian architecture decoration and form from Stright lines according to certain rules, and girih could make their own instrument (Sherbaf, 1372, p9). Therefore girih or roman rope is just one part of the patterns various part, in which could be used alone or in combination with other motifs (Najiboghloo, 1379, p.155) according to the naturalistic theme in buildings, those buildings which are covered by two or three dimentional girih pattern could tell the universe allegories. Through geometric patterns, those which have stars are most associate the sky.

Night, which is made of orbital and concentric circles reminds, starsorbit and are shining in the full star sky. The fractures lines of the various stars centre which have intersection and makes the polygons and subsidiary stars has an ambigious visual identity (Najiboghloo, 1370, p.161) "Number four is one of the most completed numbers"and is the number of divine perfection and manifestation. According to Eeclid geometry, "four" about its standing form get changed to square. (Akbari, 1389, p.88) the square is the password of the divine throne.

\begin{tabular}{|l|l|l|l|}
\hline Flower image & $\begin{array}{l}\text { Linier } \\
\text { reconstruction of } \\
\text { flower }\end{array}$ & Plant Name & row \\
\hline milfoil, yarrow & & 1 \\
\hline
\end{tabular}




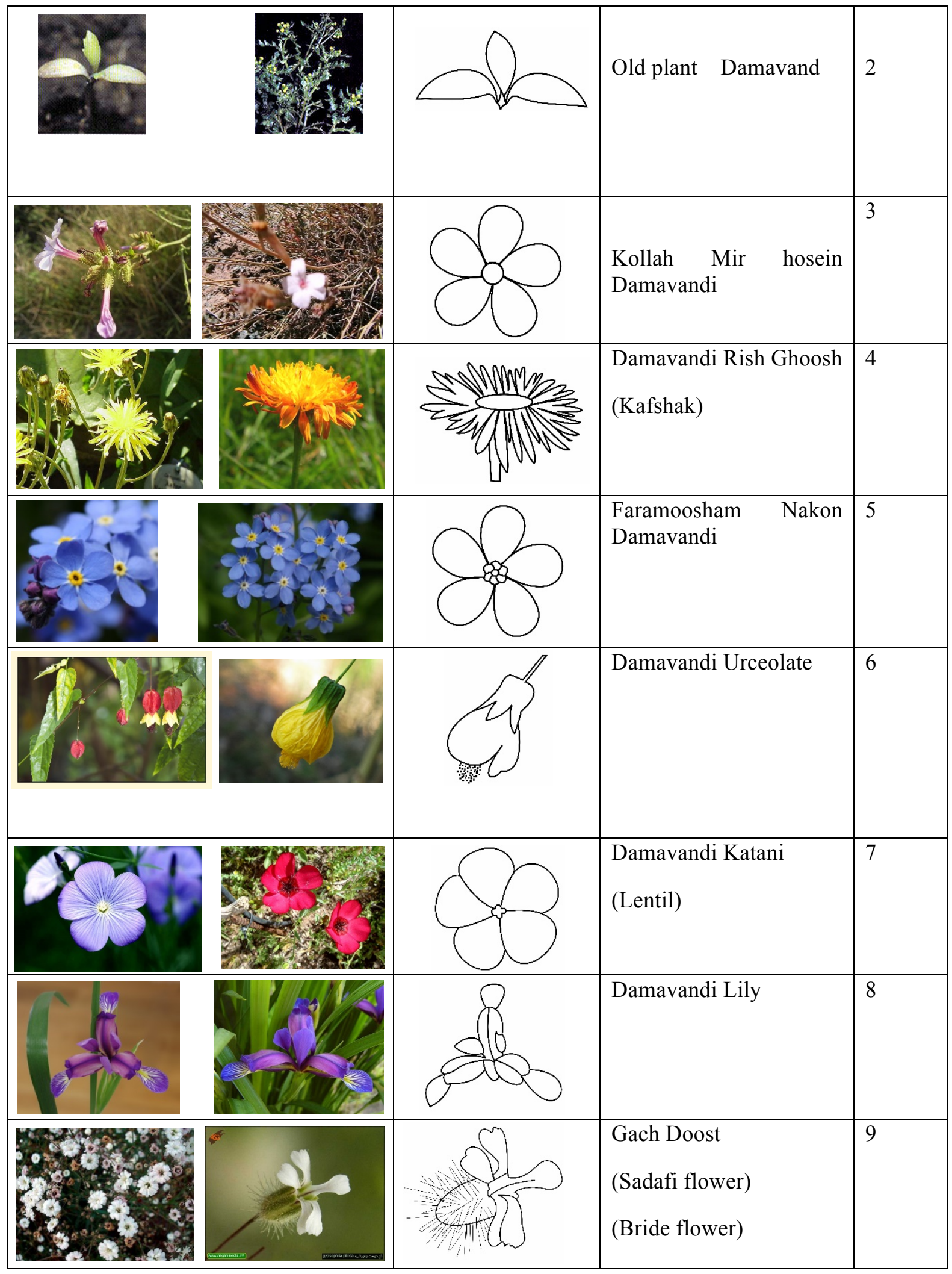




\section{CONCLUSION}

In Islamic art we faced repeated elements, such as geometric patterns or non-realistic drawing of a flower or plant which is called arabesque. Arabesque motifs in Islamic art are used as a symbol of a very vast universe that is created by god. Deliberation in not showing and imitating the nature exactly is said to be a sign of modesty of the artists who believe that creation of perfection is just for God. As a result, in the motifs and decorations of the shrines in Damavand city, the specific flowers or buds of the region are not used.

And also the motifs which represent the ceremonies and believes of the region are not seen. But artists have used motifs and decorations which follow the Iranian-Islamic culture. Iranian artists have had an important prophecy to choose natural flowers for decorating the monuments and their aim was to make a connection between the material and spiritual world. As a result, the motifs used by them are based upon Islamic concepts and are not used just as decoration. Spiritual issues are not imaginable and cannot be shown. But because they exist and they are true. Artists must use some instruments to show them and the most popular instruments is < symbol> every society specially those are committed to spirituality, must be familiar with the secrets and symbols in their culture to have a better relation with literature, art, and culture to have a better understanding of them.

Iranian artists have used common patterns because of being traditional and conservative all imitations and innovations in the world of elements make a very friendly atmosphere and would be of our essence and nature and the more delicate the changes are, the more acceptable they would be. To observe the traditional mentality. Motifs and decorations are treasures resulted from our Iranian-Islamic culture. Graphics as a new art in Iran must be taken advantage of this ancient source to express itself in the best way possible. Motifs by using the familiar language of the patterns must express the inner emotions of the society. specially in a society like Iran which people honors the past memories and old traditions.

\section{REFERENCES}

Burck hart, Titus, (1376). Sacred Art: Principles and Methods (Translation Stari, J.), Soroush Javaher ol Kalam, C 22.

Akashe, Servat, (1380), Islamic painting, translator Gholamreza Tahamy, Sooreh mehr printing. Vol first. Man la yahzarat ol faghihe, vol. 4, the Bab Manahi Payambar H. 4968, The Society of Teachers.

5. Nasr, Seyyed Hossein, (1372). (Footnote on the principles and norms of international art), Farid Shaun Hoff, in Foundations of Spiritual art (proceedings), the Office of Religious Studies Arts, Tehran.

Naghizadeh, M., (1387). From nothingness into nothingness (the roots of spiritual art), Art Quarterly (the journal Art Research Center of the Ministry of Culture), (46).

Atieh, Youzbashi. (1394). Master thesis, field of visual communications, Faculty of Arts, Shahed University, Tehran. 